Sains Malaysiana 49(6)(2020): 1345-1350

http://dx.doi.org/10.17576/jsm-2020-4906-12

\title{
Disseminated Peritoneal Lieomyomatosis After 10 Years Post TAHBSO: A Case Report
}

(Leiomiomatosis yang Tersebar di Peritoneum Selepas 10 Tahun Pasca TAHBSO: Suatu Laporan Kes)

\author{
Seyed Jalaledin Tahsildar Tehrani, Thean Yean KeW \& Mohd Amir KamaruzZaman*
}

\begin{abstract}
Disseminated peritoneal leiomyomatosis (DPL) is a rare condition characterized by the development of multiple smooth muscle-like nodules in extra-uterine region specifically in the peritoneal cavity. We introduce a case of DPL in a 50 year-old-female who presented with symptoms of abdominal pain suspicious for bowel obstruction. With the previous history of total abdominal hysterectomy and bilateral salpingo-oophorectomy (TAHBSO) since 10 years ago, bowel obstruction due to adhesion was the first provisional diagnosis. The following CT imaging of the abdomen showed a mass within the pelvis with subsequent laparotomy and evacuation of the mass. Biopsy and histopathology result showed leiomyoma. Second episode of bowel symptoms appeared one year later with abdomino-pelvic CT imaging demonstrated the recurrence of the mass at the same location within the pelvis and she was proceeded with removal of mass with similar histopathological result. While the growth of leiomyoma is mainly dependent on oestrogen hormones, absence of the ovaries as the main source of oestrogen in our case, makes it less likely to become a differential diagnosis. So far, few cases of DPL have been reported in post menopause women. This case report may bring clinical implication in term of guideline management of DPL. A careful history taking and thorough investigation with multidisciplinary experts involvement become a crucial aspect for DPL to be suspected so that the appropriate management, surgical intervention, subsequent follow up and surveillance can be achieved to improve patient outcome.
\end{abstract}

Keywords: Disseminated peritoneal leiomyomatosis; lieomyoma; post TAHBSO

ABSTRAK

Leiomiomatosis yang tersebar di peritoneum (DPL) adalah keadaan yang agak jarang berlaku yang dicirikan oleh perkembangan nodul-nodul menyerupai otot licin di luar kawasan rahim khususnya dalam ruang peritoneal. Makalah ini membincangkan tentang kes DPL pada wanita berusia 50 tahun dengan keluhan sakit perut yang disyaki mengalami penyumbatan pada saluran usus. Sumbatan usus akibat pelekatan merupakan diagnosis awal memandangkan pesakit pernah menjalani total abdominal histerektomi dan bilateral salpingo-ooforektomi (TAHBSO) sejak 10 tahun yang lalu. Kajian pada CT abdomen menunjukkan terdapat ketumbuhan pada pelvis. Pesakit seterusnya menjalani laparotomi dan ketulan tersebut dikeluarkan. Keputusan biopsi dan histopatologi menunjukkan leiomioma. Setahun kemudian, gejala usus berlaku semula dengan pencitraan CT abdomino-pelvik menunjukkan ketumbuhan berulang pada lokasi yang sama di dalam pelvis dan setelah menjalani pembedahan untuk membuang ketumbuhan tersebut, keputusan histopatologi yang sama ditunjukkan. Meskipun proses pertumbuhan leiomioma bergantung kepada hormon estrogen, ketiadaan ovari sebagai sumber utama estrogen dalam kes ini menjadikan ia bukan diagnosis pembanding untuk dipertimbangkan. Setakat ini beberapa kes DPL telah dilaporkan pada wanita pasca menopaus. Laporan kes ini mungkin membawa implikasi klinikal dengan pengambilan sejarah yang teliti dan kajian menyeluruh dengan penglibatan pakar klinikal yang multidisiplin membolehkan DPL dipertimbangkan untuk menjamin kelancaran rawatan dan pengurusan pesakit.

Kata kunci: Leiomioma; leiomiomatosis yang tersebar di peritoneum; pasca TAHBSO

\section{INTRODUCTION}

Leiomyomas are the most common gynecologic and uterine neoplasms which involves almost about $20 \%$ to $30 \%$ of female in their reproductive age (Fasih et al. 2008). Extra uterine leiomyomas, on the other hand is a rare condition of uterine smooth muscle benign tumour presented outside the uterine. Four main subtypes of extra uterine leiomyoma consist of disseminated peritoneal leiomyomatosis (DPL), benign metastasizing leiomyoma, intravenous leiomyoma, and retroperitoneal leiomyoma (Fasih et al. 2008). It can be seen almost everywhere in the body, from the lung and spine (Barber et al. 2019), to the breast (the differential diagnosis is not always simple because of radiological similarity between the different benign lesions. 


\section{CASE REPORT}

Our patient underwent THABSO operation when she was 40 years old for uterine leiomyoma. Ten years later, she presented with an abdominal colicky pain. The CT scan showed a single intra-abdominal mass with a small umbilical hernia and partial intestinal obstruction (Figures 1-3). Umbilical hernia was not the reason for partial bowel obstruction as it was an old pathology with wide neck. Thus, patient was subjected to operation and the peritoneal mass was removed and sent for histopathology. The result of pathology had proved the presence of spindle cell soft tissue tumor in favor of Leiomyoma.
A year later, patient was admitted again into the hospital with the same complaint. Subsequent CT study showed recurrence of intra-abdominal mass at the same location as the previous study with partial bowel obstruction (Figure 4). The operation was performed with removing the mass, and the result of histopathology approved multiple benign-appearing smooth muscle tumour in the abdominal cavity, consistent with leiomyomatosis peritonealis disseminata. The pathologic assessment has also showed some evidence of focal mitotically active areas, based on which further follow up was advised.

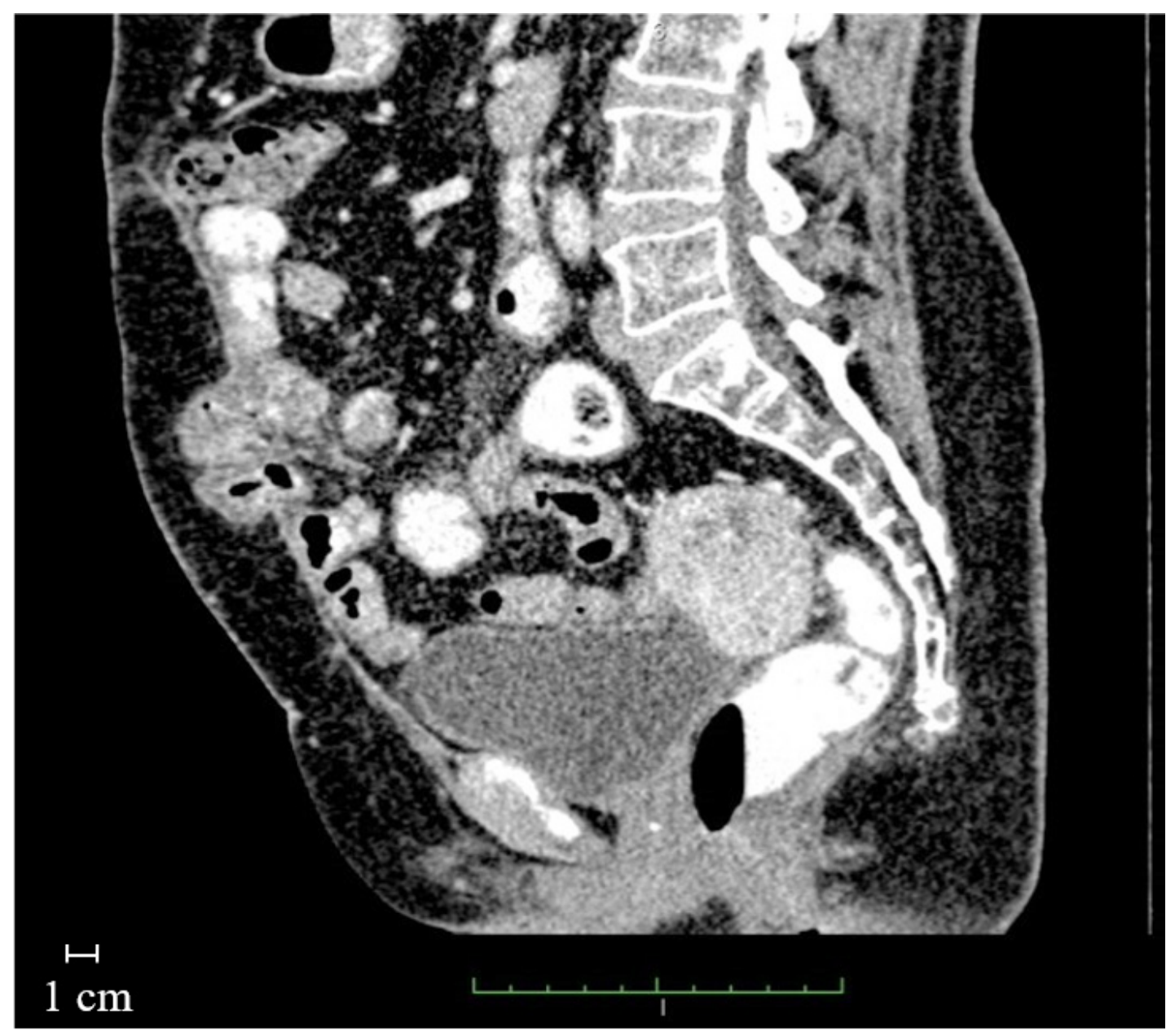

FIGURE 1. This sagittal reformate contrast enhanced CT abdomen shows absence of Uterus. Well-defined lobulated avidly enhancing mass within the pouch of Douglas superior to vaginal vault and upper rectum 


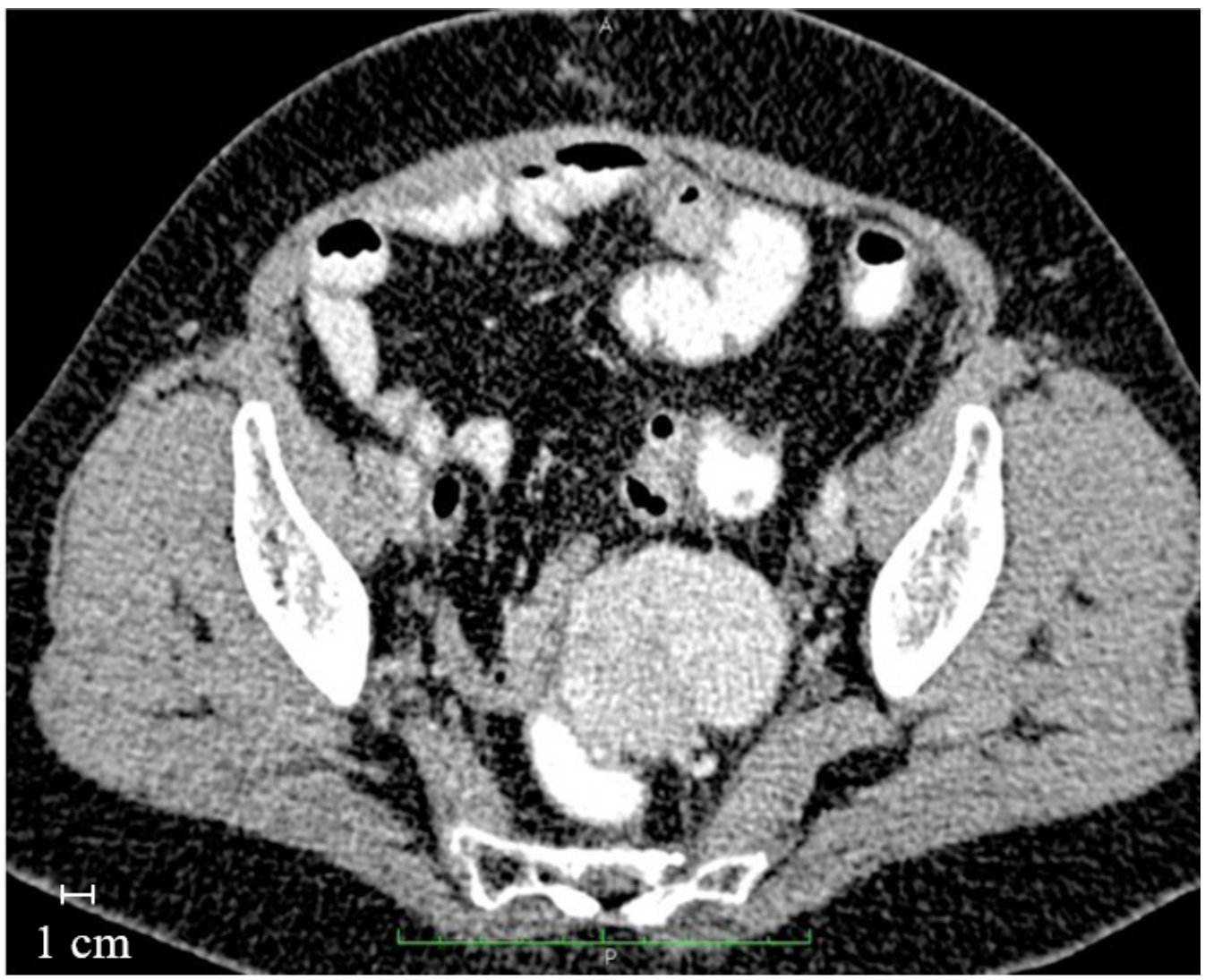

FIGURE 2. This contrast enhanced CT abdomen showing absence of Uterus and ovaries. There is also a well - defined lobulated, avidly enhancing mass within the pouch of Douglas, superior to vaginal vault and upper rectum

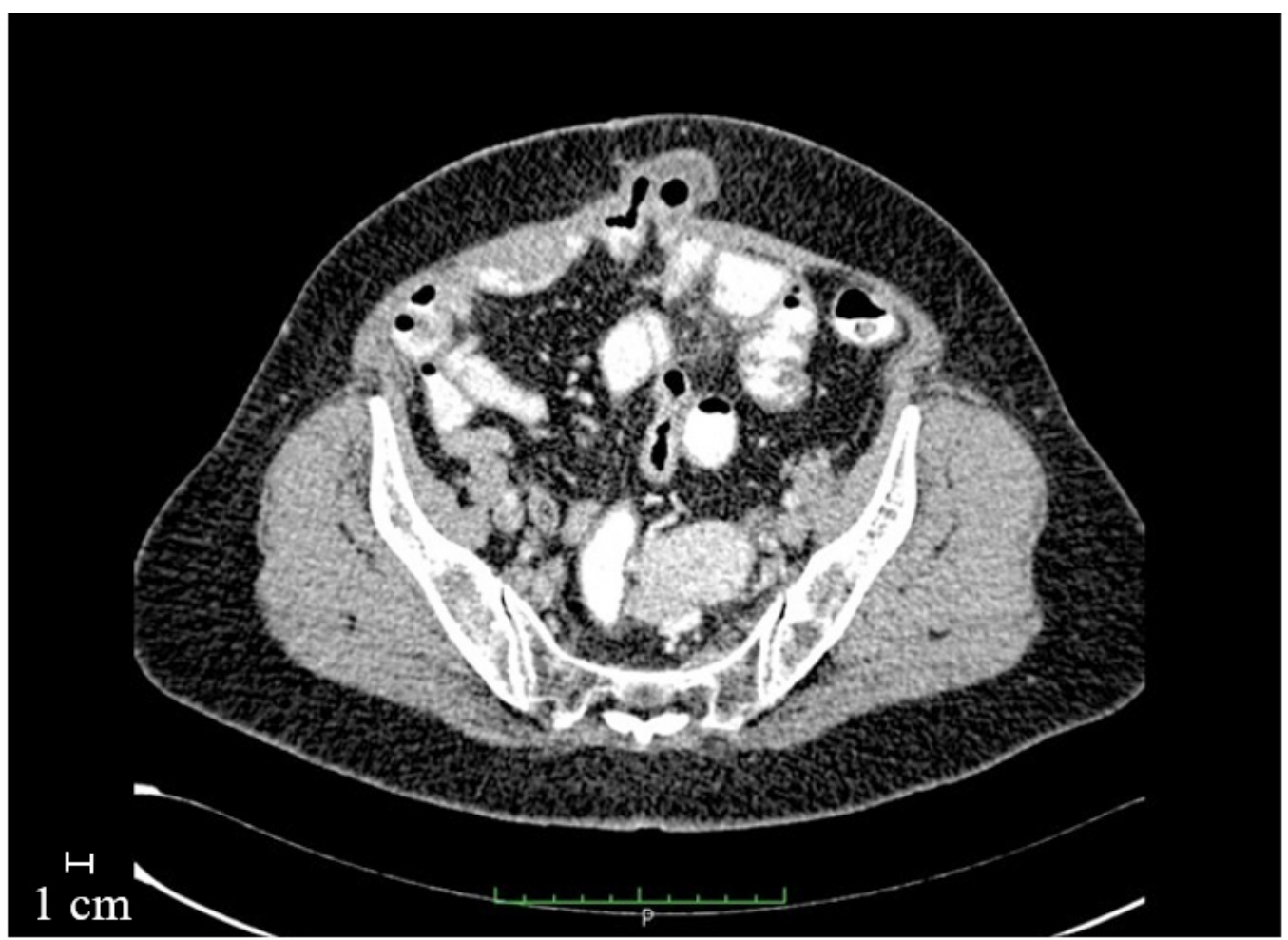

FIGURE 3. This CT image shows enhancing mass in the pouch of Douglas with no evidence of enlarged Elvis lymph nodes. Incidental finding of an anterior lower abdominal wall hernia with a loop of small bowel within 


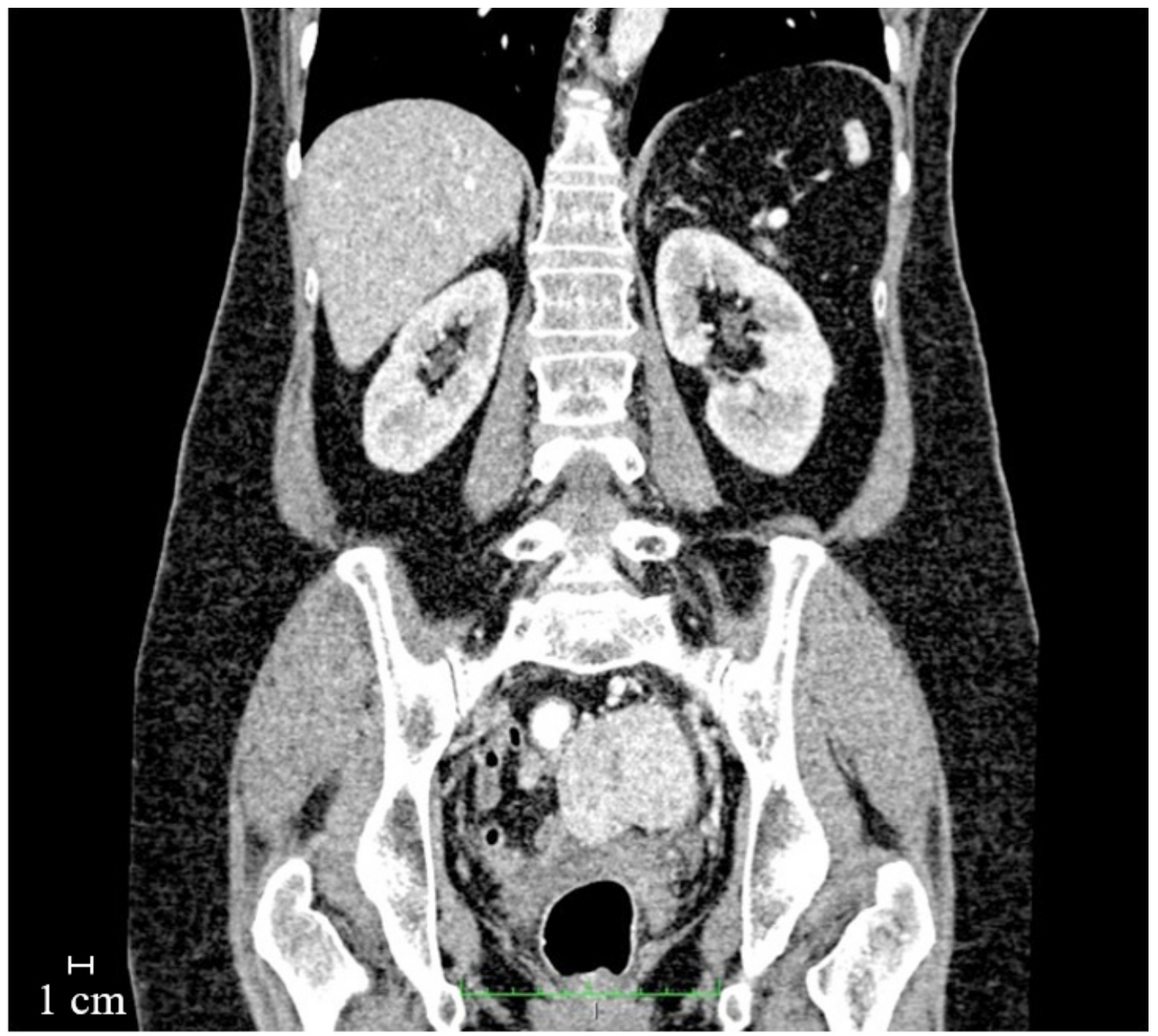

FIGURE 4. This coronal reformate CT image shows a well circumscribed enhancing pelvic mass

\section{DISCUSSION}

Leiomyoma the most common gynecologic tumour, which is benign in most of the cases (Mülayim 2015). However, there is possibility of malignant transformation, and so far near 10 cases of malignant transformation was reported (Jeyarajah et al. 2009). While the definite etiology of disseminated peritoneal leiomyomatosis (DPL) is not exactly clear, however, there are few hypothesis based on some evidences and clues presented in published cases that could have been resulted from previous surgical intervention and diagnostic instrumentation on the abdomino-pelvic region (Benton et al. 2018; Chin et al. 2014; Ciebiera et al. 2017; Jeyarajah et al. 2009; Ordulu et al. 2009; Parmar et al. 2017) resulting extrauterine seeding and disseminated of tumour particles. This consists of hormonal influence, genetic reason, and iatrogenic causes (Al-Talib \& Tulandi 2010) which commonly play role in the pathophysiologic process. Hormonal influence itself can be due to excess estrogen and progesterone levels such as long time consumption of oral contraceptive or during pregnancy or increased sensitivity and responsiveness of the receptors (Oi et al. 2018; Rezai 2017). This can justify presence of DPL in post menopause patients and may also happen in men (Wang et al. 2015). In genetic hypothesis, it is postulated that DPL and uterine leiomyoma might be due to a chromosomal abnormality of the X or other chromosomes (Al-Talib \& Tulandi 2010).

In our case, DPL was seen after 10 years post TAHBSO. This might be in favour of iatrogenic etiology. Another clue which support this idea is the recurrence of the tumour at the same place after one year. Pathologically, while this tumour is benign in most of the cases, however, there is still minimal risk of malignant transformation. In our case, the histopathology result at the second recurrence reported the evidence of active mitosis where the follow up is essential in such a condition. A few previous cases were also reported almost similar situation where 6 years post TAHBSO for DPL (Momtahan et al. 2011) and 10 years post hysterectomy 
for intra-uterine leiomyoma (Saha et al. 2015) subjected for laparotomy and mass removal eventually showed as leiomyoma in histopathology.

While in most of the time, uterine leiomyoma is readily seen in ultrasound examination of the pelvis and there is no need for further study such as CT scan since it does not have any characteristic imaging findings. DPL CT scan would be more beneficial in the case extra-uterine leiomyoma. The CT findings, depending of the size of the tumour, will show a well-defined enhancing mass (most common heterogenous). Sometimes, calcification or cystic degeneration might be seen within the mass. These features are coming within the differential diagnosis list of many other abdominal pathology, some the most important ones include peritoneal carcinomatosis, mesothelioma, tuberculosis, desmoid tumour and GIST (Gottlieb et al. 2018). Absence of enlarged abdominal lymph nodes in DPL, except in the case of malignant transformation, lack of ascites, possible location near to the myomectomy site are some other imaging points which highlight the DPL occurrence. Further differentiation can be obtained from the medical history of the patient. History of the uterine fibroid or myomectomy is the most helpful evidence.

In comparison to CT findings, MR imaging would be more accurate to diagnose DPL. As in the case of leiomyoma, it will follow the signal intensity of the muscles on both $\mathrm{T} 1$ an $\mathrm{T} 2$ sequences (Hiremath et al. 2016). In spite of all mentioned above, the definite diagnosis of DPL would be finalized by histopathology. Although imaging is beneficial to find out the exact location of the tumour, the numbers, the anatomical relation with nearby structures, presence or absence of calcification, recurrence or any further complication such as compression effect to adjacent organs or bowel obstruction.

Hormonal therapy is one of the commonest options for conservative therapy which may provide disease control, but the response rate is still not clearly elucidated. However, the systemic chemotherapy appeared to have potential response (Lin et al. 2008). Aggressive surgery, on the other hand, might bring the risk of recurrence at the site of operation due to dissemination of the tumor cells and may be reserved in the case of high-risk malignant transformation (Marwah et al. 2012).

\section{CONCLUSION}

Leiomyomas occur infrequently outside the uterus. Although they are histologically benign, extra uterine leiomyomas may mimic malignant tumors at imaging and may present a diagnostic challenge. The clinical symptoms and imaging features depend on the location of the lesion and on its growth pattern. Familiarity with potential extra uterine sites and with the complete spectrum of imaging features of these tumors, including their more unusual manifestations, facilitates their timely diagnosis and appropriate management.

\section{ACKNOWLEDGEMENTS}

We would like to thank the patient and administrative staff who keep the images for giving us kind permission to use the images in our case report.

\section{REFERENCES}

Al-Talib, A. \& Tulandi, T. 2010. Pathophysiology and possible iatrogenic cause of leiomyomatosis peritonealis disseminata. Gynecologic and Obstetric Investigation 69(4): 239-244.

Barber, E., Eapen, A., Mehta, R., Lin, E., Lane, K., Cheng, Y. \& Parajuli, R. 2019. Benign metastasizing leiomyoma to the lung and spine: A case report and literature review. Case Reports in Oncology 12(1): 218-223.

Benton, A., Sood, S., Wagner, S., Newell, J. \& Harkins, G. 2018. Disseminated peritoneal leiomyomatosis following hysteroscopic leiomyoma morcellation. Journal of Gynecologic Surgery 34(6): 319-321.

Brandão, R.G., Elias, S., Pinto Nazário, A.C., Alcoforado Assunção, M.D.C.G., Esposito Papa, C.C. \& Facina, G. 2018. Leiomyoma of the breast parenchyma: A case report and review of the literature. Sao Paulo Medical Journal 136(2): 177-181.

Chin, H., Ong, X.H., Yam, P.K.L. \& Chern, B.S.M. 2014 Extrauterine fibroids: A diagnostic challenge and a long-term battle. BMJ Case Reports 2014: p.bcr2014204928.

Ciebiera, M., Słabuszewska-Jóźwiak, A., Zaręba, K. \& Jakiel, G. 2017. A case of disseminated peritoneal leiomyomatosis after two laparoscopic procedures due to uterine fibroids. Videosurgery and Other Miniinvasive Techniques 12(1): 110-114.

Demirkiran, F., Sal, V., Kaya, U., Alhan, C. \& Tokgozoglu, N. 2013. Intravenous leiomyoma with extension to the heart: A case report and review of the literature. Case Reports in Obstetrics and Gynecology 2013: Article ID. 602407.

Fasih, N., Prasad Shanbhogue, A.K., Macdonald, D.B., FraserHill, M.A., Papadatos, D., Kielar, A.Z., Doherty, G.P., Walsh, C., McInnes, M. \& Atri, M. 2008. Leiomyomas beyond the uterus: Unusual locations, rare manifestations. Radiographics 28(7): 1931-1948.

Fatima, Q., Singh, O., Kothari, D. \& Goodara, S. 2015. Cutaneous leiomyoma of scalp: A rare case report with review of literature. International Journal of Research in Medical Sciences 3(4): 993-997.

Gottlieb, J. \& Gottlieb, R. 2018. Disseminated peritoneal leiomyomatosis. Applied Radiology 47(1): 46-47.

Hiremath, S.B., Benjamin, G., Gautam, A.A., Panicker, S. \& Rajan, A. 2016. Disseminated peritoneal leiomyomatosis: A rare cause of enigmatic peritoneal masses. BJR Case Reports 2(3): 20150252.

Jeyarajah, S., Chow, A., Lloyd, J., Zacharakis, E., Purkayastha, S. \& Tekkis, P. 2009. Follow-up in patients with disseminated peritoneal leiomyomatosis: A report of an unusual, high-risk case. BMJ Case Reports 2009: p.bcr0820080802.

Lin, Y.C., Wei, L.H., Shun, C.T., Cheng, A.L. \& Hsu, C.H. 2008. Disseminated peritoneal leiomyomatosis responds to systemic chemotherapy. Oncology 76(1): 55-58.

Marwah, N., Duhan, A., Aggarwal, G. \& Sen, R. 2012. An unusual presentation of pelvic leiomyomatosis misdiagnosed as disseminated malignancy. Case Reports in Pathology 2012: 394106 
Momtahan, M., Nemati, M. \& Safaei, A. 2011. Disseminated peritoneal leiomyomatosis. Iranian Journal of Medical Sciences 36(1): 57-59.

Mülayim, B. 2015. Unaware of a large leiomyoma: A case report with respect to unusual symptoms of large leiomyomas. Annals of Medicine and Surgery 4(4): 431-433.

Oi, Y., Katayama, K., Hirata, G., Ishidera, Y., Yoshida, H. \& Shigeta, H. 2018. Significance of postmenopausal uterine leiomyomas: Focus on variants. Journal of Obstetrics and Gynaecology Research 44(8): 1445-1450.

Ordulu, Z., Dal Cin, P., Chong, W.W.S., Choy, K.W., Lee, C., Muto, M.G., Quade, B.J. \& Morton, C.C. 2009. Disseminated peritoneal leiomyomatosis after laparoscopic supracervical hysterectomy with characteristic molecular cytogenetic findings of uterine leiomyoma. Genes, Chromosomes and Cancer 49(12): 1152-1160.

Parmar, J., Mohan, C., Hans, D. \& Vora, M. 2017. A diagnostic dilemma of recurrent disseminated peritoneal leiomyomatosis with hypertrophied omental vessels: Imaging and embolization of omental branches with positive outcome. Case Reports in Obstetrics and Gynecology 2017 : 8427240.

Rezai, S., Hughes, A., Ligorski, J., Cheung, M.L., Sarina, Lumapas., Leeping A., Henderson, C.E. \& Fulle, P.N. 2017. Disseminated peritoneal leiomyomatosis (DPL): A case report and review of literature. Obstetrics \& Gynecology International Journal 7(2): 00240.

Saha, P., Dhaliwal, L., Gainder, S., Joshi, R., Saha, S. \& Gupta, R. 2015. Disseminated peritoneal leiomyomatosis: A rare entity with diagnostic conundrum. International Journal of Reproduction, Contraception, Obstetrics and Gynecology 4(4): 1194-1196.

Shah, S.D., Gupta, A., Roy, S. \& Mukhopadhyay, S. 2013. Intraparenchymal leiomyoma of the breast: A case report. Indian Journal of Surgery 75(1): 88-89.

Sun, P., Ou, H., Huang, S., Wei, L., Zhang, S., Liu, J., Geng, S. \& Yang, K. 2017. Perianal atypical leiomyoma: A case report. Medicine 96(48): e8847.
Toriyama, A., Ishida, M., Amano, T., Nakagawa, T., Kaku, S., Iwai, M., Yoshida, K., Kagotani, A., Takahashi, K., Murakami, T. \& Okabe, H. 2013. Leiomyomatosis peritonealis disseminata coexisting with endometriosis within the same lesions: A case report with review of the literature. International Journal of Clinical and Experimental Pathology 6(12): 2949-2954.

Wang, X., Ren, J., Chen, G. \& Xu, S. 2015. Giant abdominal leiomyoma of male: A case report and literature reviews. International Journal of Clinical and Experimental Pathology 8(7): 8532-8535.

Willson, J.R. \& Peale, A.R. 2016. Multiple peritoneal leiomyomas associated with a granulosa-cell tumor of the ovary. American Journal of Obstetrics and Gynecology 64(1): 204-208.

Seyed Jalaledin Tahsildar Tehrani \& Thean Yean Kew Department of Radiology

Faculty of Medicine

UKM Medical Centre

Canselor Tuanku Mukhriz Hospital

Jalan Yaacob Latiff

56000 Cheras, Kuala Lumpur, Federal Territory

Malaysia

Mohd Amir Kamaruzzaman*

Department of Anatomy

Faculty of Medicine

UKM Medical Centre

Canselor Tuanku Mukhriz Hospital,

Jalan Yaacob Latiff

56000 Cheras, Kuala Lumpur, Federal Territory

Malaysia

*Corresponding author; email: mohdamir@ukm.edu.my

Received: 25 April 2019

Accepted: 31 January 2020 